\title{
PENGARUH SENAM PROLANIS TERHADAP PENURUNAN TEKANAN DARAH PADA LANSIA DI DESA GLAGAHWERO KECAMATAN PANTI KABUPATEN JEMBER
}

\author{
Lutfiasih Rahmawati $^{1 *}$, Nailul Aizza ${ }^{2}$ \\ Fakultas Keperawatan Universitas Jember \\ Jl. Kalimantan No. 37 Kampus Tegal Boto Jember Telp./Fax. (0331) 323450 \\ *e-mail: lutfiasih.psik2013@gmail.com
}

\begin{abstract}
ABSTRAK
Hipertensi merupakan salah satu penyakit degenerative yang banyak ditemukan di Indonesia, ditandai oleh kenaikan tekanan darah diatas nilai normal yang dapat diakibatkan oleh berbagai macam faktor. Penelitian ini bertujuan untuk mengetahui pengaruh senam Prolanis terhadap penderita hipertensi. Jenis penelitian ini ialah ekperimental lapangan dengan pre-post test one group design. Sampel penelitian berjumlah 22 orang lansia yang diperoleh melalui purposive sampling. Senam Prolanis dilakukan selama 4 minggu. Analisis data menggunakan uji t berpasangan. Hasil penelitian memperlihatkan terdapat perbedaan bermakna antara tekanan darah sistolik awal dan akhir pada latihan 2 kali/minggu $(\mathrm{p}=0,003<\alpha=0,001)$; antara tekanan darah diastolik awal dan akhir pada latihan $2 \mathrm{kali} /$ minggu $(\mathrm{p}=0,002<\alpha=0,001)$. Terdapat perubahan rerata tekanan darah sebelum dan sesudah latihan senam baik pada latihan $2 \mathrm{kali} /$ minggu. Simpulan pada kedua kelompok latihan terdapat penurunan bermakna tekanan darah sistolik dan diastolik setelah senam Prolanis selama 4 minggu berturut-turut.

Kata kunci: senam prolanis, hipertensi
\end{abstract}

\section{ABSTRACT}

Hypertension is one of the degenerative diseases commonly found in Indoensia. It is characterized by an increase of blood pressure above its normal level and is caused by various factors. This study aimed to obtain the influence of Prolanis exercise on hypertensive patients. This was an experimental field study with a pre-post test one group design conducted for 4 weeks. There were 25 respondents in this study obtained by using purposive sampling. Data were analyzed with the paired t-test.The results showed that there were significant differences between before and after two-times-per-week Prolanis exercise in systolic blood pressure $(p=0,003<\alpha=0,001)$ and in diastolic blood pressure $(p=0,002<$ $\alpha=0,001)$. There were changes in mean blood pressure before and after Prolanis exercise two times per week. Conclusion: In the two groups, there were significant decreases of systolic and diastolic blood pressures after Prolanis exercise for 4 weeks consecutively.

Keywords: senam Prolanis, hypertension

\section{PENDAHULUAN}

Hipertensi merupakan gangguan sistem peredaran darah yang menyebabkan kenaikan tekanan darah diatas nilai normal, yaitu melebihi $140 / 90$ mmHg. Hipertensi dapat menimbulkan kerusakan organ tubuh, baik secara langsung maupun tidak langsung. Kerusakan organ target yang umum ditemui pada pasien hipertensi adalah penyakit ginjal kronis, jantung, otak, penyakit arteri perifer, dan retinopati.

Menurut American Heart Association (AHA), hipertensi adalah penyakit dimana terjadi peningkatan tekanan darah sistolik $>140 \mathrm{mmHg}$ atau tekanan darah diastolik $>90 \mathrm{mmHg}$. Secara umum penyebab hipertensi ialah umur, jenis kelamin, perilaku, aktivitas fisik, tingginya kadar kolesterol darah 
serta diabetes melitus. Di Amerika menurut National Health and Nutrition Examination Survey (NHNES III) paling sedikit $30 \%$ pasien hipertensi tidak menyadari kondisi mereka, dan hanya $31 \%$ pasien yang diobati mencapai target tekanan darah yang diinginkan di bawah 140/90 mmHg. Pada penelitian di Amerika oleh American Hypertension Association (2006) ditemukan hanya 68\% penderita hipertensi yang mengetahui penyakit tersebut, sisanya sama sekali tidak mengetahui penyakit tersebut, dan diperkirakan $30 \%$ penduduknya (kurang lebih 50 juta jiwa), menderita tekanan darah tinggi dengan persentase biaya kesehatan cukup besar setiap tahunnya. Sekitar $80 \%$ kenaikan kasus hipertensi terjadi terutama di negara-negara berkembang.

Prevalensi hipertensi di Indonesia mencapai $31,7 \%$ dari populasi usia 18 tahun ke atas, dimana jumlah itu $60 \%$ penderita mengalami penyakit jantung, gagal ginjal, pada semua umur di Indonesia (Riskesdas, 2010) sampai dengan umur 55 tahun laki-laki lebih banyak menderita hipertensi dibandingkan dengan perem-puan, dari umur 55 tahun sampai dengan 74 tahun, sedikit lebih banyak perempuan dibanding laki-laki yang menderita hipertensi. Pada populasi lansia (umur $\geq 60$ tahun), prevalensi untuk hipertensi sebesar $65,4 \%$.

Hasil Riset Kesehatan Dasar (Riskesdas) Nasional tahun 2007 menunjukkan prevalensi hipertensi berdasarkan pengukuran termasuk kasus yang sedang minum obat, secara nasional sebesar 28,3 \%. Menurut WHO, batas tekanan darah masih dianggap normal ialah $<130 / 85 \mathrm{mmHg}$, sedangkan bila $>140 / 90 \mathrm{mmHg}$ dinyatakan sebagai hipertensi. Tekanan darah tinggi adalah suatu peningkatan tekanan darah didalam arteri. Hipertensi ini sering ditemukan pada usia lanjut. Tekanan sistolik terus meningkat sampai usia 55-60 tahun, kemudian berkurang secara perlahan dan menurun drastis.
Hipertensi pada dasarnya memiliki sifat yang cenderung tidak stabil dan sulit dikontrol. Hipertensi adalah suatu keadaan dimana seseorang mengalami peningkatan tekanan darah diatas normal yang mengakibatkan peningkatan angka kesakitan (morbiditas) dan angka kematian (mortalitas).

Olahraga menyebabkan perubahan besar pada sistem sirkulasi dan pernapasan dimana keduanya berlangsung bersamaan sebagai respon homeostatik. Latihan olahraga yang sering digunakan pada penderita hipertensi adalah olahrga aerobik. Banyak bentuk olahraga aerobik yang dapat ditempuh oleh pasien hipertensi antara lain jogging dan senam aerobic. Olahraga teratur dapat menurunkan tekanan sistolik maupun diastolik pada orang dengan hipertensi tingkat ringan.

Latihan fisik sangat berpengaruh bagi penurunan tekanan darah dalam meningkat-kan imunitas tubuh setelah latihan teratur, mengatur kadar glukosa darah, mencegah kegemukan, meningkatkan sensitivitas reseptor insulin, menormalkan tekanan darah serta meningkatkan kemampuan kerja. Senam aerobik dapat membantu memperbaiki profil lemak darah, menurunkan kolesterol total, Low Density Lipoprotein (LDL), trigliserida dan menaikkan High Density Lipoprotein (HDL) serta memperbaiki sistem hemostatis dan tekanan darah.

Salah satu program pemerintah yaitu senam Prolanis (Program Pengelolahan Penyakit Kronis) merupakan bentuk latihan jasmani aerobik. Senam ini juga termasuk program pemerintah yang dijalankan oleh Badan Penyelengaraan Jaminan Sosial (BPJS). Prolanis adalah suatu sistem pelayanan kesehatan dan pendekatan proaktif yang dilaksanakan secara terintegrasi yang melibatkan peserta, fasilitas kesehatan dan BPJS (Badan Penyeleng-garaan Jaminan Sosial) Kesehatan dalam rangka pemeliharan kesehatan bagi peserta yang menyandang penyakit kronis untuk 
mencapai kualitas hidup yang optimal dengan biaya pelayanan kesehatan yang efektif dan efisien.

Penelitian ini bertujuan untuk mengetahui pengaruh program Prolanis yang dijalankan oleh BPJS khususnya Senam Prolanis terhadap penurunan tekanan darah.

\section{METODE}

Jenis penelitian ini ialah eksperimental lapangan dengan pre-post group design. Penelitian dilaksanakan pada bulan November 2015 - Desember 2015 di Klinik Husada Sario Manado. Pengambilan sampel dilakukan dengan purposive sampling pada lansia yang didiagnosis hipertensi di Klinik Husada. Kriteria inkulsi penelitian ini ialah pasien berumur 40 tahun ke atas penurunan tekanan darah yang bersedia ikut dalam penelitian serta

menandatangani informed conset. Responden yang memenuhi kriteria inklusi, dikumpulkan untuk diberikan penjelasan tentang Senam Prolanis. Sebelum latihan senam dilakukan pemeriksaan tekanan darah. Responden dibagi dua kelompok yaitu 2 kali/seminggu dan $3 \mathrm{kali} /$ seminggu selama 4 minggu melakukan latihan senam dalam waktu 30 menit. Setelah diberikan latihan selama 4 minggu, tekanan darah responden diperiksa lagi.

Data dianalisis dengan uji $t$ berpasangan untuk mengetahui ada tidaknya perbedaan pengamatan. Uji statistik dijalankan dengan menggunakan perangkat lunak SPSS (Statistical Program For Social Science) versi 22,0

\section{HASIL}

Pada penelitian ini diperoleh respon-den 25 orang penurunan tekanan darah yang telah memenuhi kriteria inklusi (Tabel 1). Jumlah responden perempuan $(77,3 \%)$ lebih bantak dari lakilaki $(22,7 \%)$.
Tabel 1. Distribusi frekuensi berdasarkan Jenis kelamin

\begin{tabular}{ccc}
\hline Jenis Kelamin & Jumlah & $\mathbf{( \% )}$ \\
\hline Perempuan & 17 & 77,3 \\
Laki-laki & 5 & 22,7 \\
Total & 22 & 100,0 \\
\hline
\end{tabular}

Pada Tabel 2 dapat dilihat bahwa jumlah responden yang terbanyak ialah berumur $45-55$ tahun $(54,5 \%)$ dan yang paling sedikit ialah berumur 61-70 tahun $(18,2 \%)$.

Tabel 2. Distribusi Frekuensi Berdasarkan Umur

\begin{tabular}{ccc}
\hline Umur (tahun) & Jumlah & $(\mathbf{\% )}$ \\
\hline $45-50$ & 12 & 54,5 \\
$51-60$ & 6 & 27,3 \\
$61-70$ & 4 & 18,2 \\
Total & 22 & 100,0 \\
\hline
\end{tabular}

Tabel 3 memperlihatkan pada kelompok latihan 2 kali/minggu dengan tekanan darah sistolik sebelum latihan 140 $\mathrm{mmHg}$ terjadi penurunan sesudah latihan menjadi $130 \mathrm{mmHg}$; dan tekanan darah diastolik sebelum latihan yaitu $84 \mathrm{mmHg}$ mengalami juga penurunan sesudah latihan menjadi $77 \mathrm{mmHg}$.

Tabel 3. Kelompok Latihan 2 kali/minggu (Tekanan Darah Sistolik dan Diastolik Sebelum dan Sesudah Latihan )

\begin{tabular}{cccc}
\hline \multicolumn{2}{c}{ Tekanan darah } & \multicolumn{2}{c}{ Tekanan darah } \\
Sistolik $(\mathbf{m m H g})$ & Diastolik & $(\mathbf{m m H g})$ \\
\hline Sebelum & Sesudah & Sebelum & Sesudah \\
140 & 130 & 84 & 77 \\
\hline
\end{tabular}

Hasil uji statistik pada kedua kelompok latihan yaitu kelompok latihan $2 \mathrm{kali} /$ minggu rerata tekanan darah sistolik awal dan akhir serta tekanan darah diastolik awal dan akhir maka perlu dilakukan pengujian kenormalan data dengan hasil uji tidak menyebar normal (Sig <0,05); oleh sebab itu dilakukan uji perbedaan yaitu uji Wilcoxon signed 
ranks pada masing-masing kelompok latihan (Tabel 4).

Tabel 4. Hasil uji kelompok latihan 2 kali/minggu

\begin{tabular}{ccc}
\hline & T & $\begin{array}{c}\text { Asymp Sig. } \\
\text { (1-tailed) }\end{array}$ \\
\hline Tekanan Darah & 6,243 & 0,001 \\
Sistolik Akhir - & & \\
Tekanan Darah & & \\
Sistolik Awal & & \\
Tekanan Darah & 6,197 & 0,001 \\
Diastolik Akhir - & & \\
Tekanan Darah & & \\
Diastolik Awal & & \\
\hline
\end{tabular}

Tabel 4 memperlihatkan terdapat perbedaan bermakna antara tekanan darah sistolik awal dan akhir pada latihan 2 kali/minggu $(p=0,003<\alpha=0,001)$; terdapat perbedaan bermakna antara tekanan darah diastolik awal dan akhir pada latihan $2 \mathrm{kali} /$ minggu $(\mathrm{p}=0,002<\alpha$ $=0,001)$;

\section{PEMBAHASAN}

Penelitian dilakukan terhadap 22 orang pasien hipertensi di Desa Glagahwero yang mengikuti senam Prolanis yang dialkukan latihan 2 kali/minggu. Perlakuan berupa senam Prolanis selama 60 menit. Responden didominasi oleh jenis kelamin perempuan (77,3\%) (Tabel 1). Umur respon-den berkisar 45-80 tahun terbanyak pada kisaran 45 - 50 tahun $(54,5 \%)$ (Tabel 2).

Tabel 3 memperlihatkan bahwa didapatkan penurunan baik tekanan darah sistolik maupun tekanan darah diastolik setelah latihan. Hasil penelitian ini serupa dengan penelitian oleh Rismayanthi ${ }^{13}$ yang mendapatkan perbedaan bermakna tekanan darah diastolik pada penderita hipertensi stadium sedang sebelum dan sesudah melakukan senam aerobic. Rerata yang diperoleh tekanan darah diastolik sebelum perlakuan sebesar 103,733 dan rerata tekanan darah diastolik sesudah perlakuan sebesar 99,300. Dengan demikian dapat dikatakan, bahwa terjadi penurunan bermakna dari tekanan darah sesudah perlakuan senam aerobic low impact pada penderita hipertensi stadium sedang.

Berdasarkan Tabel 4 terdapat perbedaan bermakna antara tekanan darah sistolik awal dan akhir latihan ( $\mathrm{p}=0,003$ $<\alpha=0,001)$ dan terdapat perbedaan bermakna antara tekanan darah diastolik awal dan akhir latihan $(\mathrm{p}=0,002<\alpha=$ 0,001). Hal ini menunjukkan bahwa terdapat perbedaan bermakna tekanan darah sistolik dan diastolik antara sebelum dan sesudah latihan.

Latihan olahraga yang dilakukan agar dapat berpengaruh terhadap efisiensi kerja jantung. Sebaiknya latihan berada pada intensitas sedang yaitu denyut jantung 150-170/menit. Intesitas sedang $\leq 70-80 \%$ dari kapasitas aerobik maksimal. Intesitas latihan adalah lamanya yang dilakukan, khususnya latihan yang bersifat aerobik dan intesitas latihan yang paling penting harus dipenuhi. Frekuensi latihannya 3- 5 kali seminggu dengan lama latihan 20-60 menit sekali latihan. Latihan olahraga dapat menyebabkan dilatasi pembuluh-pembuluh darah sehingga tekanan darah menurun. Orang yang melakukan latihan 3 kali seminggu akan mengalami peningkatan daya tahan kardiorespirasi dan latihan olahraga secara teratur bisa menurunkan resiko penyakit jantung.

Rismayanthi mendapatkan bahwa olahraga aerobik terutama bermanfaat untuk meningkatkan dan mempertahankan kesehatan dan daya tahan jantung, paru, peredaran darah, otot- otot, dan sendisendi. Senam aerobic low impact mempunyai pengaruh besar terhadap tubuh, khususnya terhadap daya tahan paru dan jantung.

Latihan fisik sangat berpengaruh bagi penderita hipertensi untuk meningkatkan imunitas dalam tubuh setelah latihan teratur, meregulasi kadar glukosa darah, mencegah kegemukan, meningkatkan sensitivitas reseptor insulin, 
menormalkan tekanan darah serta meningkatkan kemampuan kerja. Senam aerobik dapat membantu memperbaiki profil lemak darah, menurunkan kolesterol total, Low Density Lipoprotein (LDL), trigliserida dan menaikan High Density Lipoprotein (HDL) serta memperbaiki sistem hemostatis dan tekanan darah.

\section{KESIMPULAN}

Berdasarkan hasil penelitian pada 22 responden yang diberi perlakuan senam Prolanis dapat disimpulkan bahwa pada kedua kelompok latihan terdapat penurunan bermakna tekanan darah sistolik dan diastolik setelah senam Prolanis selama 4 minggu berturut-turut.

\section{SARAN}

Lansia hendaknya secara teratur melakukan senam prolanis sebagai salah satu perawatan terhadap tekanan darah.

\section{KEPUSTAKAAN}

American Hypertension Association. 2006. Alternative Treatments Hypertension. Available form: http:// healthlibrary. epnet. com/print.

Armilawaty, Amalia, H., Amirudin, R. 2007. Hipertensi dan Faktor Resikonya dalam kajian Epidemiologi. Makassar: Bagian Epidemiologi FKM UNHAS,.

Barnason, S., Zimmerman, Nieveen, J. 2007. Effectiveness of Community Health Workers in the Care of People with Hypertension. Am J Prev Med.

Caspersen, C., Powell, K., Christenson, G. 1985. Physical activity, exercise, and physical fitness: Definitions and distinctions for health-related research. Public Health Rep.; 100:126-31.

Kamus Kedokteran Dorland. 2010. (31st ed). Jakarta: EGC.

Puji, I., Heru, S., Agus, S. 2007. Pengaruh Senam aerobik. Media Ners.;1(2):49-99.
2015. Diabetes Melitus Tipe 2 dan Hipertensi (diakses 5 Oktober 2015).

Kusmana, D. 2006. Olahraga Untuk Orang Sehat dan Penderita Penyakit Jantung. Jakarta: Balai Penerbit Fakultas Kedokteran Universitas Indonesia,.

Kusmana, D. 2002. Olahraga Bagi Kesehatan Jantung. Jakarta: Fakultas Kedokteraan Universitas Indonesia,.

Riskesdas. 2010. Laporan Riset Kesehatan Dasar. Jakarta: Badan Penelitian dan Pengembangan Kesehatan Kementerian Kesehatan RI.

Riskesdas. 2007. Laporan Riset Kesehatan Dasar Tahun. Jakarta: Badan Penelitian dan Pengembangan Kesehatan Kementerian Kesehatan RI.

Ridjab, DA. 2005. Pengaruh Aktifitas fisik terhadap Tekanan Darah. Jurnal Kedokteran Atmajaya.;4(2):73.

Rismayanthi, C. 2009. Pengaruh Latihan Senam Jantung Indonesia Terhadap Penurunan Tekanan Darah pada Penderita Hipertensi [Tesis]. Yogyakarta: Pps IK UNY.

World Health Organization. 2010. Global Recommendations on Physical Activity for Health. Switzerland, 